\title{
Assessment of students' attitude and level of community involvement in community-based education at training sites in Gedeo zone, South Ethiopia
}

\author{
Mohammed Feyisso Shaka ${ }^{1 *}$ (1) and Gedefa Amenu Senbeto ${ }^{2}$
}

\begin{abstract}
Objective: This study was aimed to assess the students' attitude towards community based education and the level of community involvement in community-based education.

Result: Among the 634 community members participated in this study, $64.4 \%$ were aware of the community-based education program and $86.5 \%$ of these participants have favorable attitude towards the program. The level of community involvement in the activities of students in this study is $40.9 \%$. About $72 \%$ of the students have favorable attitude towards community based education. Female students were more likely to have favorable attitude toward the program [AOR: $7.64(\mathrm{Cl}$ 1.80, 32.50)]. On the other hand, students who have low participation during group assignment [AOR: $0.07(\mathrm{Cl} 0.01,0.95)]$ and those with lower socially conscious attitude [AOR: $0.02(0.01,0.08)]$ were less likely to have favorable attitude.
\end{abstract}

Keywords: Community-based education, Students' attitude, Community involvement

\section{Introduction}

Innovative medical schools currently use communitybased education (CBE) as one of the means for training of health experts who are responsive to the needs of a society [1]. During CBE, community is used extensively as a learning environment. Furthermore, there is active engagement of students, instructors, community members, different sectors and agencies throughout the community based-education process. CBE is commonly operated by training institutions to enhance the quality of education, and also as a means to retain health professionals in underserved areas. This approach was primarily arose to contribute for "Health for All" strategy through enhancing PHC program [2].

CBE is aimed to widen students' insight of health problems of a community through their learning, service and

\footnotetext{
*Correspondence: mamfys8@gmail.com

${ }^{1}$ School of Public Health, Dilla University College of Health Sciences and Medicine, Dilla, Ethiopia

Full list of author information is available at the end of the article
}

research work [3]. It involves identifying of community health problems (community diagnosis) and searching for solutions through engagement of stakeholders in the community [4-6].

The two commonly practiced community-based education programs in medical trainings in Ethiopia are community based training program (CBTP) and team training program (TTP) [7]. The practice of each community-based education varies from country to country and from institution to institution. The students' learning process is spiral in nature and problem-solving in approach. During their stay in the community, students exercise different learning oriented community based activities including data gathering, community diagnosis, planning, implementation and evaluation. During their active involvement in this program, the students gain a sense of social responsibility and detail understanding of the community health and social problems as well as solutions within local resources $[4,5,8,9]$.

$\mathrm{CBE}$ is a powerful means of improving quality of the community health services. Students also acquire a skill 
to mobilize the community in implementing community development projects and using available community resources. The community resources could be in the form of labor, local material, space or money (in cash or in kind) to cover most of the intervention costs.

The main focus of this study was to assess the attitude of students toward $\mathrm{CBE}$ and the level of community involvement on activities during the program.

\section{Main text \\ Methods \\ Study design and area}

The institution and community-based quantitative study, which was supplemented by a qualitative enquiry, was conducted from March 6, 2017 to June 28, 2017. The study population was comprised of the community members of three towns (Dilla, Yirgacheffie, and Wonago) in the Gedeo zone of Ethiopia and final-year students from all the departments of the Dilla University College of Health Sciences and Medicine who had communitybased education $(\mathrm{CBE})$ as part of the core competency in their education curriculum [10].

\section{Sample size calculation and sampling technique}

The sample size of students was the entire graduating class of students from the specified departments. For community-based, the sample size was calculated using a single population proportion formula as follows:

$$
\mathrm{N}=\frac{\mathrm{Z} \frac{\alpha}{2} \mathrm{pq}}{\mathrm{d} 2},
$$

where $\mathrm{Z} \frac{\alpha}{2}=1.96, \mathrm{p}=50 \%, \mathrm{q}=1-\mathrm{p}=50 \%$, and $\mathrm{d}=0.5$.

The calculated sample size was 384 , after considering the design effect of 1.5 and a $10 \%$ nonresponse rate, the final sample size was 634 . The sample size for the qualitative study was determined based on the data saturation.

Three kebeles (local districts) from Dilla, one from Wonago, and two from Yirgacheffie were selected using a simple random sampling method. The respondents were selected by a systematic random sampling method based on the arrangement of the households in the selected towns.

\section{Data collection instruments and personnel}

The tools used in the study were developed by reviewing the literature that was pertinent to the study. Cronbach's alpha reliability coefficient was checked for each question, resulting in $\geq 0.7$. For the data collection among students, three facilitators were recruited to assist in the completion of the questionnaire. Eleven data collectors and three supervisors were used for the communitybased house-to-house data collection.

\section{Measurement}

The attitude of the students toward CBE was assessed by using a range of questions that were measured with a Likert scale. Scores greater than the average value were classified as having a favorable attitude. To create the scale for the socially-conscious attitude of the students, two asked the reason why they selected health science as their future career. The statements were "Helping people to improve their health" and "Having a role in improving community health." Scores ranged from 2 to 10, and scores from 2 to 6 were categorized as low, scores from 7 to 8 were categorized as average, and scores of 9 to 10 were categorized as high. The level of the community members' involvement was also assessed by using questions that inquired about participation in the activities of students during the $\mathrm{CBE}$.

\section{Data analysis}

Data was entered into a template format prepared from EpiData version 3.1 and exported to SPSS version 20 for analysis. Descriptive statistics were computed for the attitude of students toward CBE and the level of involvement of the community. Logistic regression was used to assess factors associated with attitude of students towards CBE.

\section{Result \\ Awareness and attitude of communities and students towards community-based education}

Out of the 634 community members expected to participate in the study 631 successfully responded. Regarding the awareness of community members, 406 (64.4\%) were aware of the presence of the CBE program in their locality. Among them, 347 (86.5\%) have a favorable outlook towards students' activities during communitybased education (Table 1). However, only $146(36.6 \%)$ of the respondents rated good or above on the scale for the contribution of community-based education program to improve the health of the community in the study area, whereas $166(41.6 \%)$ rated fair and $87(21.8 \%)$ rated poor or below.

Out of the 197 graduating class students of June 2017 in Dilla University College of Health Sciences and Medicine, 188 participated in this study. Based on a measurement of the socially conscious attitude of the students, 129 (70.5\%) were enthusiastic towards helping people, i.e., they have average or above socially conscious attitude. In comparison, about 133 (72\%) of the students have a favorable attitude towards community-based education.

Regarding the perceived benefit of community-based education for students and community, only 56 (30.1\%) of the students reported that they have gained high 
Table 1 Awareness and attitude of communities about the community-based training program and their involvement in CBE activities, Gedeo zone, South Ethiopia, July 2017

\begin{tabular}{|c|c|c|c|}
\hline No. & Variables & Frequency & Percentage (\%) \\
\hline \multirow[t]{3}{*}{1.} & $\begin{array}{l}\text { Heard or seen CBE activities of } \\
\text { students }\end{array}$ & 630 & $100 \%$ \\
\hline & Yes & 406 & 64.4 \\
\hline & No & 224 & 35.6 \\
\hline \multirow[t]{4}{*}{2.} & Attitude of community toward CBE & & \\
\hline & Favorable & 347 & 86.5 \\
\hline & Neutral & 47 & 11.7 \\
\hline & Unfavorable & 7 & 1.7 \\
\hline \multirow[t]{3}{*}{3.} & $\begin{array}{l}\text { Participated on the students } \\
\text { activities }\end{array}$ & 401 & $100 \%$ \\
\hline & Yes & 164 & 40.9 \\
\hline & No & 237 & 59.1 \\
\hline \multirow[t]{4}{*}{4.} & $\begin{array}{l}\text { Way of involvement in students' } \\
\text { activities }\end{array}$ & 167 & $100 \%$ \\
\hline & $\begin{array}{l}\text { Participating personally on activi- } \\
\text { ties }\end{array}$ & 120 & 73.1 \\
\hline & Providing money/material & 3 & 1.8 \\
\hline & Mobilizing communities & 44 & 26.8 \\
\hline \multirow[t]{6}{*}{5.} & $\begin{array}{l}\text { Reported reason for not participat- } \\
\text { ing in CBE activities }\end{array}$ & 235 & $100 \%$ \\
\hline & Not around & 84 & 35.4 \\
\hline & No invitation from students & 122 & 51.5 \\
\hline & Don't want to participate & 8 & 3.4 \\
\hline & No skill to participate & 7 & 3.0 \\
\hline & Other reason & 14 & 5.9 \\
\hline
\end{tabular}

competence from CBE. The overall students' evaluation of their skills obtained from $\mathrm{CBE}$ is a little above average (3.6 out of 6). However, about $83.2 \%$ of the students rated the advantage of CBE to community as average or above (Table 2; Additional file 1).

\section{Participation of communities in the activities of students during $C B E$ practice}

Among the 402 community members who were aware of the presence of the CBE program in their locality, only 164 (40.9\%) had ever participated in CBE activities (Table 3). Most of these participants were involved during the initial stage of data collection (43.3\%) and during the implementation/intervention phase (45.7\%). The level of participation during prioritization and planning was significantly limited, which is $8 \%$ and $6 \%$ respectively. Similarly, $<50 \%$ of the students rated the overall community participation in CBE to be high, whereas only $44 \%$ rated above average for support from health sector institutions (Table 2).
Table 2 Students rating of community involvement in CBE practice and importance of CBE, Gedeo Zone, South Ethiopia, July 2017

\begin{tabular}{|c|c|c|c|}
\hline No. & Variables & Frequency & Percentage (\%) \\
\hline \multirow[t]{4}{*}{1.} & Community involvement & 188 & $100 \%$ \\
\hline & Poor & 48 & 25.5 \\
\hline & Average & 51 & 27.1 \\
\hline & High & 89 & 47.3 \\
\hline \multirow[t]{4}{*}{2.} & $\begin{array}{l}\text { Support from health sectors in the } \\
\text { area }\end{array}$ & 188 & $100 \%$ \\
\hline & Poor & 37 & 20.3 \\
\hline & Average & 65 & 35.7 \\
\hline & High & 80 & 44.0 \\
\hline \multirow[t]{4}{*}{3.} & Advantage of CBE for community & 184 & $100 \%$ \\
\hline & Poor & 31 & 16.8 \\
\hline & Average & 73 & 39.7 \\
\hline & High & 80 & 43.5 \\
\hline \multirow[t]{5}{*}{4.} & $\begin{array}{l}\text { Perceived competence obtained } \\
\text { from } \mathrm{CBE}\end{array}$ & 182 & $100 \%$ \\
\hline & Low & 36 & 19.7 \\
\hline & Fair & 91 & 49.7 \\
\hline & High & 56 & 30.6 \\
\hline & Average & 3.6 & - \\
\hline
\end{tabular}

\section{Factors associated with students' attitude toward CBE}

In this study attempts were made to assess factors associated with the students' attitude towards communitybased education. As it can be noted from the result, sex of the students, perceived level of the students' participation during usual group assignments in the class and their socially conscious attitude were associated with the attitude towards community-based education.

Accordingly, female students were nearly eight times more likely to have favorable attitude towards community-based education compared to male students [AOR: 7.64 (CI 1.80, 32.50)]. On the other hand, students whose participation during usual group assignment in a class was reported to be low were 93\% less likely to have favorable attitude toward $\mathrm{CBE}$ compared to those who have higher participation [AOR: 0.07 (CI $0.01,0.95)]$. Similarly, the likelihood of having favorable attitudinal outlook towards CBE was decreased by $98 \%$ for students whose socially conscious attitude was low compared to those with higher socially conscious attitude [AOR: $0.02(0.01,0.08)$ ] (Table 3).

\section{Discussion}

In this study, most community members and stakeholders had a favorable attitude toward the activities performed by students during CBE. This finding is consistent 
Table 3 Factors associated with students' attitude towards community-based education among students of College of Health Sciences and Medicine, Dilla University, South Ethiopia, July 2017

\begin{tabular}{|c|c|c|c|c|c|}
\hline \multirow[t]{2}{*}{ No } & \multirow[t]{2}{*}{ Variables } & \multicolumn{2}{|l|}{ Attitude } & \multirow[t]{2}{*}{$\operatorname{COR}(95 \% \mathrm{Cl})$} & \multirow[t]{2}{*}{ AOR $(95 \% \mathrm{CI})$} \\
\hline & & $\begin{array}{l}\text { Not favorable } \mathrm{n}=51 \\
(27.7 \%)\end{array}$ & $\begin{array}{l}\text { Favorable, } n=133 \\
(72 \%)\end{array}$ & & \\
\hline \multirow[t]{3}{*}{1.} & \multicolumn{5}{|l|}{ Age category } \\
\hline & 22 and below & 18 & 57 & 1 & 1 \\
\hline & 23 and above & 33 & 76 & $0.73(0.37,1.42)$ & $1.77(0.53,5.95)$ \\
\hline \multirow[t]{3}{*}{2.} & \multicolumn{5}{|l|}{ Sex } \\
\hline & Male & 31 & 78 & 1 & 1 \\
\hline & Female & 20 & 55 & $1.09(0.56,2.11)$ & $7.64(1.80,32.50)$ \\
\hline \multirow[t]{5}{*}{3.} & \multicolumn{5}{|l|}{ Department } \\
\hline & Health officer & 20 & 81 & 1 & 1 \\
\hline & Midwifery & 7 & 13 & $0.46(0.16,1.30)$ & $5.18(0.94,28.60)$ \\
\hline & Psychiatry & 17 & 5 & $0.07(0.02,0.22)$ & $0.46(0.07,3.11)$ \\
\hline & Medicine & 7 & 34 & $1.20(0.46,3.10)$ & $2.15(0.44,10.50)$ \\
\hline \multirow[t]{3}{*}{4.} & \multicolumn{5}{|l|}{ Section } \\
\hline & Regular & 47 & 98 & 1 & 1 \\
\hline & Extension & 4 & 35 & $4.20(1.41,12.50)$ & $0.32(0.07,1.55)$ \\
\hline \multirow[t]{4}{*}{5.} & \multicolumn{5}{|c|}{ Participation during group work } \\
\hline & Low & 11 & 2 & $0.05(0.01,0.22)$ & $0.07(0.01,0.95)$ \\
\hline & Fair & 23 & 59 & $0.63(0.31,1.29)$ & $0.23(0.07,0.79)$ \\
\hline & High & 17 & 69 & 1 & 1 \\
\hline \multirow[t]{3}{*}{6.} & \multicolumn{5}{|c|}{ Joined the department by choice } \\
\hline & Yes & 33 & 113 & 1 & 1 \\
\hline & No & 18 & 20 & $0.32(0.15,0.68)$ & $2.67(0.51,14.26)$ \\
\hline \multirow[t]{4}{*}{7.} & \multicolumn{5}{|c|}{ Satisfaction with the joined department } \\
\hline & Not satisfied & 7 & 15 & $0.48(0.17,1.31)$ & $0.31(0.08,1.23)$ \\
\hline & Neutral & 22 & 18 & $0.18(0.08,0.39)$ & $0.27(0.06,1.30)$ \\
\hline & Satisfied & 22 & 99 & 1 & 1 \\
\hline \multirow[t]{4}{*}{8.} & \multicolumn{5}{|c|}{ Socially conscious attitude } \\
\hline & Low & 37 & 16 & $0.04(0.02,0.11)$ & $0.02(0.01,0.08)$ \\
\hline & Average & 6 & 30 & $0.49(0.16,1.54)$ & $0.96(0.26,3.62)$ \\
\hline & High & 8 & 81 & 1 & 1 \\
\hline
\end{tabular}

with the findings from other studies $[7,11]$. This is also supported by the findings from a qualitative study. A health extension worker from one of the towns said, "The students can significantly contribute to the improvement of the health of the communities and support our routine work" and the head of a certain health office stated, "The students can contribute much to improve the health of the community from what they have learned...."

Approximately $72 \%$ of the students indicated a favorable attitude towards $\mathrm{CBE}$, which also coincided with the socially conscious attitude of students that was used to measure their enthusiasm. This is supported by the findings from a study conducted in Iran [11]. Female students were found to be more likely to have a favorable attitude toward CBE. This may have been due to the difference in the behaviors of males and females. It also demonstrated that students who are more enthusiastic about serving the community have a more favorable attitude toward CBE since the pillar of $\mathrm{CBE}$ activities is understanding the specific problems of the communities and developing strategies to tackle the problems. Students who had a poor rating on their participation level for typical group assignments during class-based/clinical attachments were less likely to have a positive attitude toward CBE. This is due to the fact that students who had participated in previous group assignments had a good exposure to the teamwork that they would actually face during CBE.

Regarding the level of involvement of the communities in the activities of students during CBE, only $40.9 \%$ participated in the students' activities. In addition, the extent of participation was relatively low for those 
communities that did not participate during key periods of the program, such as prioritization and planning. Since communities are the main stakeholders of the CBE practice, this level of involvement is much lower than it should be and may be related to the inadequate effort of students to mobilize and involve community members. Students were rated as less than average for their efforts in communicating about each CBE activity within the community. This is similar to the findings from the study conducted at Jimma University where the overall community participation in $\mathrm{CBE}$ was found to be low $[7,12]$.

According to the results of the qualitative section of this study, the level of involvement of the people responsible, including health extension workers, is relatively poor. For example, a 32-year-old health extension worker from one of the towns stated, "I haven't participated in any of the students' activities, I haven't asked them about what they do, and they don't communicate anything about their activities with us." Although participation of the health center in the study area is relatively better, it is substantially limited. There is limited communication between the heads of the health office or health center and the students when preparing an action plan and its implementation, as well as poor communication of details and intervention reports with the stakeholders. The head of a certain health center in the study area stated that "one problem I realized through my work experience here is that they don't consult us during the planning and implementation. They also do not communicate with us to let us know what they found in the community and what they improved." The findings specifically suggest that the students' and the supervisors' behaviors for motivating and mobilizing communities to participate in $\mathrm{CBE}$ activities is poor.

In general, the level of community involvement is substantially low and the students' attitude toward CBE is not adequate. Since communities are the main stakeholders of CBE, a special arrangement to tangibly improve community involvement in the program and develop a sense of ownership needs to be created.

\section{Limitation of this study}

Scope of the study being limited to one cohort of medical school students.

\section{Additional file}

Additional file 1. Socio-demographic characteristics of students and community members.
Abbreviations

CBE: community based education; CBTP: community based training program; HEW: health extension workers; PHC: primary health care; SPSS: statistical package for social science; TTP: team training program.

\section{Authors' contributions}

MF conceived the idea, analyzed, interpreted and prepared manuscript. GA assisted on writing the proposal, analysis, interpretation and preparation of manuscript. Both authors read and approved the final manuscript.

\section{Author details \\ ${ }^{1}$ School of Public Health, Dilla University College of Health Sciences and Medi- cine, Dilla, Ethiopia. ${ }^{2}$ Department of Midwifery, Dilla University College of Health Sciences and Medicine, Dilla, Ethiopia.}

\section{Acknowledgements}

We would like to extend our heartfelt gratitude and appreciation to Dilla University College of Health Sciences and Medicine for financial support. Our deep appreciation also goes to the respondents of the study for their willingness and cooperation to participate in the study. At last but not least, we deeply appreciate Dr. Taddese Jalata (Associate professor) for his unreserved effort for language and grammar revision.

\section{Competing interests}

The authors declare that there is no competing interests.

\section{Availability of data and materials}

The data of this study is readily available and could be obtained from the corresponding author on reasonable request at any time.

\section{Consent to publish \\ Not applicable.}

\section{Ethics approval and consent to participate}

Ethical clearance was obtained from Institutional Review Board of Dilla University College of Health Sciences and Medicine. Informed consent was obtained from all of the respondents prior to the interview and the purpose of the study was explained to the respondents in detail. Participation was completely voluntary and the participants were well informed about the right to with draw from the study at any time or choose not to participate. Confidentiality of the information obtained was assured and privacy of the respondents during giving the consent and data collection was also maintained.

\section{Funding}

The source of funding for this study is Dilla University and there is no any role of the funding body in the design of the study, data collection, analysis, and interpretation, and in writing the manuscript.

\section{Publisher's Note}

Springer Nature remains neutral with regard to jurisdictional claims in published maps and institutional affiliations.

Received: 7 September 2018 Accepted: 21 November 2018 Published online: 26 November 2018

References

1. Talib ZM, Baingana RK, Sagay AS, Van Schalkwyk SC, Mehtsun S, KiguliMalwadde E. Investing in community-based education to improve the quality, quantity, and retention of physicians in three African countries. HHS Public Access. 2014;26(2):109.

2. Woldemariam T, Asefa M. Historical perspective of Jimma Institute of Health Sciences. Bull JHS. 1990;1(2):11-9.

3. Diab P, Flack P. Benefits of community-based education to the community in South African health science facilities. Afr J Prim Health Care Fam Med. 2013;5(1):474.

4. UNESCO. International conference on education, 38th session, Geneva, 10-19 November 1981. In Paris; 1982. p. 38. 
5. WHO. Community based education for health personnel. Technical report series 746. Geneva: WHO; 1987.

6. Richards R, Fulop T. Innovative schools for health personnel. WHO offset Publication, No. 102. Geneva; 2007.

7. Tegegne M, Asefa M, Tessema F, Kebede K. Assessment of the community-based training programme at Jimma University, Ethiopia. Ethiop J Health Dev. 2000;2:240-52.

8. Asefa M. Community-based education: concept and practice. Ethiop J Health Dev. 2000;14:227-38.

9. Richards R, Fulop T. Innovative schools for health personnel. WHO offset Publication, No. 102. Geneva; 1987.
10. Dilla University. Dilla University community based education guideline. Dilla: Dilla University; 2017.

11. Movahhed T, Ajami B, Ghasemi H, Shakeri T, Sufiani M, Health CO, et al. The attitude toward community based education among dental students at an Iranian Dental School. Future Med Educ J. 2013;3:24-8.

12. Ibrahim N, Bekele M. Assessing the impact of community based training program of Jimma University on improving livestock health in Jimma Zone. Afr J Basic Appl Sci. 2014;6(6):166-70.
Ready to submit your research? Choose BMC and benefit from:

- fast, convenient online submission

- thorough peer review by experienced researchers in your field

- rapid publication on acceptance

- support for research data, including large and complex data types

- gold Open Access which fosters wider collaboration and increased citations

- maximum visibility for your research: over $100 \mathrm{M}$ website views per year

At BMC, research is always in progress.

Learn more biomedcentral.com/submissions 